\title{
PERKEMBANGAN PSIKOLOGIS DALAM PERTANGGUNGAN JAWAB PERISTIWA PIDANA
}

\author{
Oleh: ${ }^{1}$ Chainur Arrsyid \\ (Fakultas Hukum Universitas Sumatera Utara) \\ Email:chainur@gmail.com
}

\begin{abstract}
ABSTRAK
Psikologi perkembangan, maka deviasi-deviasi (penyimpangan-penyimpangan) tingkah laku manusia dapat dicegah, karena psikologi perkembangan merupakan salah satu dasar manta untuk menghantar dalam rangka membahas aspek kejiwaan perbuatan kriminil Menurut penelitian kehidupan manusia itu mengalami grafik kehidupan jasmani maupun kejiwaan, Sejak usia muda sampai usia tua serta setiap waktu usia tertentu terjadi cerobahan perobahan-perobahan hidup yang mempunyai ciri-ciri khas sendiri. Berdasarkan adanya perobahan-perobahan dan ciri-ciri khas tersendiri dari usia tertentu itu, psikologi telah mengadakan pembahagian masa-masa itu setiap para ahli mempunyai pembagian yang berbeda-beda, tetapi materi peristiwa tersebut mempunyai persamaan.

Kata Kunci : Perkembangan, Psikologis, Pertanggungan, Jawab, Pidana.
\end{abstract}

\begin{abstract}
Developmental psychology, deviations (deviations) in human behavior can be prevented, because developmental psychology is one of the bases of manta to deliver in order to discuss the psychological aspects of criminal acts. According to research, human life experiences a graph of physical and psychological life, since a young age until old age and at any given age, changes in life occur which have their own characteristics. Based on the changes and distinctive characteristics of a certain age, psychology has held a division of the period, each expert has different divisions, but the material of these events has in common.
\end{abstract}

Keywords: Development, Psychological, Coverage, Answer, Criminal. 


\section{A. PENDAHULUAN}

I. Perbuatan Dan Kaedah Masyarakat Masyarakat manusia beraneka ragam berkelompok dan bergelombang serta mempunyai variasi kehidupan yang berbeda. Variasi kehidupan masyarakat tersebut terlihat dari ciri-ciri khas kebudayaan manusia tertentu yang bertebar dialam ini. Ciri-ciri khas kebudayaan masyarakat tertentu itu menimbulkan penilaian yang berbeda terhadap sikap kebudayaan umat manusia.

Demikian juga terhadap tingkah laku atau perbuatan yang merupakan suatu aspek dari kebudayaan itu. Perbuatan atau tingkah laku yang dinilai serta mendapatkan reaksi yang bersifat tidak disukai oleh masyarakat tertentu, merupakan suatu tindakan yang tidak dibenarkan untuk muncul ditengahtengah kehidupan masyarakat. Sebab itulah dalam rangka memberikan pengertian kejahatan sangat tergantung kepada penilaian dan jenis reaksi yang diberikan oleh masyarakat dimana terjadi perbuatan itu. Secara sosiologis kejahatan itu sebagai gejala yang mempunyai ciriciri khas yang dapat dirasakan dan diketahui oleh masyarakat tertentu. Masalahnya terletak pada penilaian yang dihadapkan kepada kaedah-kaedah yang berlaku di dalam masyarakat itu.

Prof. Mahadi, SH dalam kuliahnya mengatakan "Kaedah-kaedah itu mungkin berasal dari atas maupun dari bawah yang muncul dari masyarakat yang telah dipatuhi Juga kaedah itu dapat berbentuk tertulis maupun kebiasaan serta adat yang berlaku dalam masyarakat tertentu.

Meskipun demikian perlu juga diperhatikan tentang pergeseranpergeseran terhadap nilai perbuatan yang telah ada sehubungan dengan perbuatan sebagai gejala sosial. Hal ini disebabkan bahwa kelompok dan gabungan masyarakat. berjenis-jenis dan punya ciri- ciri khasnya sendiri serta situasi dan kondisi kehidupan yang berbeda-beda dan tentu pula penilaian terhadap perbuatan tersebut juga mengalami pergeseran-pergeseran.

Prof Dr.J.E. Sahetapy, SH, mengatakan "Seringkali orang mengira bahwa kalau orang berbicara tentang hukum, berarti orang secara implisit berbicara pula tentang keadilan. Memang harus diakui bahwa hukum dan keadilan begitu erat berkaitan, sehingga rasanya seolah-olah tidak masuk akal kalau orang berbicara tentang.

\section{B. HASIL DAN PEMBAHASAN}

II. Pertanggung Jawab Peristiwa Pidana

Selanjutnya sanksi apa yang harus ditetapkan kepada pelaku perbuatan jahat yang secara definitif telah ditentukan, haruslah bertitik tolak antara kejahatan dalam pengertian hukum - pidana dengan kejahatan dalam pengertian di luar hukum pidana. Di dalam pengertian hukum pidana kejahatan itu secara definitif telah ditetapkan di dalam KUHP maupun delik-delik Pidana Khusus yang terdapat di luar KUHP tersebut. Secara definitif maksudnya KUHP itu sendiri secara tegas telah menetapkan jika suatu perbuatan telah memenuhi unsur-unsur yang terdapat di dalam ketentuanketentuan pasalnya, maka perbuatan tersebut dianggap kejahatan tertentu serta disebut jenis kejahatannya.

Pengertian kejahatan diluar Hukum Pidana adalah setiap perbuatan yang dapat merugikan orang lain, tetapi secara definitif perbuatan itu tidak ditetapkan aleh Undang-undang Hukum Pidana.

Meskipun demikian baik jenis kejahatan yang telah terdapat di dalam Hukum Pidana maupun di luar Hukum Pidana, kedua-duanya mempunyai sanksi hukum. Sanksi hukum terhadap kejahatan dalam pengertian Hukum Pidana jelas tercantum di dahun Hukum Pidana itu sendiri. Sedangkan sanksi-sanksi 
terhadap kejahatan diluar Hukum Pidana, rasa keadilan masyarakatlah yang menentukannya. Kembali kepada sanksisanksi hukum terhadap kejahatan dalam pengertian hukum pidana, khususnya di dalam KUH Pidana Indonesia maupun delik-delik khusus yang terdapat di luar KUHP Indonesia, ketentuan sanksinya jelas ditetapkan. Jika kita perhatikan di dalam Buku II, dan Buku Ill KUHP Indonesia, maupun delik-delik khusus, yang terdapat di luar KUH Pidana Indonesia, ternyata tidak menetapkan secara tegas berat hukumnya. Setiap Pasal hanya menetapkan batas maximal huum yang dapat diputuskan.

Jadi dalam hal ini keputusan yang ditetapkan terletak antara batas maximum tersebut.

Misalnya delik pencurian yang terdapat dalam Pasal 362 KUHP Indonesia, berbunyi: "Barang siapa mengambil sesuatu barang, yang sama sekali atau sebagian termasuk kepunyaan orang lain, dengan maksud akan memiliki barang itu dengan melawan hak, dihukum karena pan, curian, dengan hukuman penjara selama-lamanya lima tahun atau denda sebanyak=banyaknya Rp.900.-"

Pasal 362 KUH Pidana ini adalah "pencurian biasa" unsur-unsurnya:

a. Perbuatan "mengambil"

b. Yang diambil harus "suatu barang"

c. Barang itu harus seluruhnva atau sebagian "kepunyaan prang lain"

d. Bengambilan itu harus dilakukan dengan maksud untuk "memiliki" barang dengan "melawan hukum" (melawan hak).

Kalau unsur-unsur ini semuanya telah terpenuhi, maka si pelaku perbuatan tersebut sudah memenuhi syarat-syarat Pasal KUH Pidana dengan istilah "pencurian biasa". (R. Susilo, hal. 249).

Karena itu hakim dapat menetapkan hukuman antara batas maximal sesuai dengan Pasal 362 KUH Pidana tersebut, yakni sampai lima tahun dan denda maximal Rp. 900.- Sehubungan dengan batas maximal berat hukuman ini cukup menarik untuk dikemukakan, karena mengapa tidak ditetapkan saja secara tegas tanpa menentukan batas maximal tersebut. Mungkin dapat ditafsirkan motivasi dari pada beratnya sanksi hukum yang terdapat di dalam setiap jenis kejahatan berbeda-beda dan bahkan Hakim diberi kebebasan untuk mempertimbangkan berat ringannya hukuman tanpa melewati batas maximal hukuman yang telah ditetapkan. Disamping itu terdapatnya pengecualianpengecualian hukuman, maupun peringanan-peringanan dan pemberatanpemberatan hukuman yang terdapat di dalam Hukum Pidana. Khusus pengecualian-pengecualian hukuman, walaupun jelas perbuatan. itu merupakan peristiwa pidana, tetapi si pelaku kejahatan diberikan pengecualian hukuman. KUH Pidana Indonesia Buku I, mengatur tentang Pengecualianpengecualian hukuman inn seperti yang terdapat di dalam:

Pasal 44 ayat 1

"Tidak dikenakan hukuman terhadap barangsiapa yang melakukan sesuatu perbuatan pidana, yaw, tidak dapat

dipertanggungjawabkan kepadanya, disebabkan karena kurang sempurnanya kemampuan berpikir atau karena sakit ingatannya".

Pasal 48

"Tidak dikenakan hukuman kepada barangsiapa melakukan sesuatu perbuatan pidana karena terdorong oleh keadaan yang tidak dapat dikuasainya"

Pasal 49 ayat (1)

"Tidak diberikan hukuman kepada barangsiapa melakukan perbuatan pidana karena beta paksa yang diamarkan oleh pembelaan yang tak dapat dielakkan guna keselamatan jiwanya sendiri atau orang lain, kehormatan sendiri atau orang lain, 
atau milik kepunyaan sendiri atau orang lain, terhadap perkosaan tanpa hak atau mengancam sesaat itu juga".

Pasal 49 ayat (2)

"Tidak dikenakan hukuman terhadap perbuatan yang melampaui batas-batas pembelaan yang sangat perlu jikalau hal itu disebabkan perasaan rusuh seketika sebagai akibat dari pemerkosaan terhadapnya".

\section{Pasal 50}

"Tidak dikenakan hukuman kepada barangsiapa melakukan perbuatan pidana waktu menjalankan peraturan hukum"

Pasal 51 ayat (1)

"Tidak dikenakan hukuman kepada barangsiapa melakukan perbuatan pidana untuk melakukan perintah jabatan, yang diberikan oleh pembesar yang berhak".

Pasal 51 ayat (2)

"Perintah jabatan yang diberikan oleh pembesar yang tidak berhak, tidak membebaskan orang dari hukuman, kecuali jika dengan iktikad haik yang melakukan beranggapan bahwa pembesar yang memberikan perintah itu termasuk kewajibannva sebagai bawahan".

Pasal 53 ayat (1) (2) dan

(Percobaan) ayat (1) berbunyi:

"Percobaan untuk melakukan kejahatan terancam hukuman bila maksud si pembuat sudah nyata dengan dimulainya perbuatan itu dan perbuatan itu tidak jadi sampai selesai hanya lantaran hal yang tidak tergantu.ng dari kemauannya sendiri".

Ayat 2 berbunyi:

"Maximum hukuman utama yang diadakan bagi kejahatan dikurangkan

dengan sepertiganya, dalam hal percobaan"

Ayat (3) berbunyi:

"Jika kejahatan itu diancam dengan hukuman mati, atau hukuman penjara seumur hidup maka bagi percobaan, dijatuhkan hukuman penjara selamalamanya lima belas tahun".
Pasal 57 ayat (1) dan (2) (membantu) Ayat (1) berbunyi:

"Selama-lamanya hukuman pokok dan kejahatan, dikurangi dengan sepertiganya, dalam hal membantu melakukan kejahatan"

Ayat (2) berbunyi:

"Jika kejahatan itu diancam dengan hukuman mati atau hukuman penjara seumur hidup maka dijatuhkanlah hukuman penjara selama-lamanya lima belas tahun"

Pasal 47 ayat (I) dan (2) (Belum dewasa) Ayat I berbunyi:

"Jika hakim menghukum si tersalah maka maximum hukuman utama yang ditetapkan atas perbuatan yang patut dihukum itu dikurangi dengan sepertiganya".

Ayat 2 berbunyi:

"Jika, kejahatan itu diancam dengan hukuman mati atau penjara secumu hidup maka dihukum penjara selama-lamanya lima belas tahun".

Pasal 52 (Kedudukan sebagai Pejabat)

"Jikalau seorang pegawai negeri melanggar kewajibannya yang istimewa

dalam jabatannya yang dibolehkan hukum atau pada waktu melakukan perbuatan yang boleh dilakukan memakai kekuasaan, kesempatan atau daya upaya yang diperoleh dari jabatannya maka hukumannya boleh ditambah dengan sepertiganya"

Bab VI, Buku 1, (Gabungan)

Mengenai "gabungan" ini diatur dalam Pasal 63 s/d 71, dan jika kita perhatikan ternyata, secara tegas pelaku-pelaku kejahatan tersebut dapat diperberat hukumannya.

III. Pertimbangan Psikologis

Secara anthropologis kita mempunyai persamaan-persamaan dan perbedaanperbedaan jika ditinjau dari aspek kebudayaan, yakni berupa aspek tingkah laku, tata kelakuan Jan hasil kelakuan itu. Khusus tentang tingkah laku adalah 
merupakan suatu masalah yang sangat serius dalam kriminologi. Misalnya terletak bahwa tingkah laku itu mempunyai kawasan luas, ada tingkah laku yang dianggap bermoral, tetapi ada yang asosial dan bahkan bersifat kriminil.

Walaupun tingkah laku yang dianggap asosial maupun kriminil itu merupakan tingkah laku normal yang ada pada diri setiap manusia, tetapi sebagai manusia yang bermasyarakat dan berkebudayaan sudah semestinya harus dicegah atau diusahakan untuk tidak membuatnya. Inilah tugas berat bagi individu antara manusia itu. Perbuatan kriminil maupun asosial tidak dikehendaki dalam hidup bermasyarakat, begitu juga secara religius atau keagamaan walaupun tingkahlaku seperti ini merupakan suatu aspek sang wajar dan ada pada diri manusia, tetapi hal ini harus tidak muncul dalam kehidupan manusia itu. Dapatlah kami katakan bahwa usaha untuk mengatasinya cukup berat, karena manusia itu sudah terikat oleh perbuatan yang tidak disenangi. Perhatikan keawal kehidupan manusia, bagaimana sakitnya derita seorang ibu sewaktu ada gerakan-gerakan janin dalam kandungannya dan juga pada saat melahirkan Dihadapan hukum penilaiannya memang berbeda, tetapi apakah dari segi kenyataan bukankah itu suatu perbuatan yang merugikan dan

menyakiti orang lain. Untuk memahami kehidupan manusia diperlukan suatu pemahaman khusus tentang eksistensi manusia tersebut, yang berarti pula mengetahui aspirasi, perasaan, cita-cita dan gejolak-gejolak jiwa manusia. Tentu ini dapat dipelajari dalam psikologi.

Dengan mendalami psikologi perkembangan, maka deviasi-deviasi (penyimpangan-penyimpangan) tingkah laku manusia dapat dicegah, karena psikologi perkembangan merupakan salah satu dasar manta untuk menghantar dalam rangka membahas aspek kejiwaan perbuatan kriminil Menurut penelitian kehidupan manusia itu mengalami grafik kehidupan jasmani maupun kejiwaan, Sejak usia muda sampai usia tua serta setiap waktu usia tertentu terjadi cerobahan perobahan-perobahan hidup yang mempunyai ciri-ciri khas sendiri.

Berdasarkan adanya perobahanperobahan dan ciri-ciri khas tersendiri dari usia tertentu itu, psikologi telah mengadakan pembahagian masa-masa itu setiap para ahli mempunyai pembagian yang berbeda-beda, tetapi materi peristiwa tersebut mempunyai persamaan. Pembagian masa-masa kehidupan hanyalah berdasarkan teori dan tidak bersifat mutlak, karena hanya sekedar untuk menemukan pelajaran tentang perkembangan kehidupan manusia pada

umumnya. Antara masa kemasa merupakan suatu rangkaian yang tak terputus karena sangat retatif untuk mengadakan pemisahan secara mutlak alas usia manusia itu. Secara relatif hanya dapat menetapkan tingkat-tingkat usia tertentu untuk memisahkan satu masa

kemasa kehidupan berdasarkan terdapatnya perbedaaan atau ciri khas yang tidak terdapat pada masa lainnya.

Sesuai dengan perkembangan manusia tersebut, tentu saja dalam perkembangannya terlihat serangkaian perobahan sifat dan corak. Sebab itulah terlihat adanya ciri-ciri khas tertentu dalam setiap mesa perkembangan kehidupan manusia. Penggolongan masa perkembangan terdapat beberapa konsep yang dikemukakan para ahli tetapi tentang batas usia di dalam setiap golongan masa tidak diperoleh secara tegas. Meskipun demikian banyak persamaan-persamaan yang dijumpai dalam pembagian masa-masa perkembangan. Dengan tidak mengabaikan tolak kepada pembagian masa-masa perkembangan dengan 
mengambil batasan secara umum tentang batas usia yang dapat merupakan pedoman dalam mempelajari tingkah laku manusia.

Menurut para ahli, selama kehidupan ternyata manusia itu mengalami tiga kali gelombang masa, yakni masa progresip, masa stabil dan masa regresip. Masa progresip merupakan masa pertumbuhan dan perkembangan baik pisik maupun psikhis. Psikhisnya berkembang dari fungsi yang paling sederhana mengarah kefungsi yang paling kompleks. Pada masa ini manusia menemui dua kali masa krisis kehidupan besar dan merupakan lampu merah dalam hidup ini. Dimasa

krisis ini terjadi kegoncangankegoncangan kejiwaan maupun fisik yang menempatkan seseorang itu dalam keadaan yang harus diperhatikan serta mendapatkan pengarahan dan bimbingan yang serius. Dimasa stabil tidak terdapat lagi perobahan-perobahan yang besar baik pisik maupun psikhisnya, karena dalam masa ini adalah merupakan pengukuhan fungsi-fungsi yang sudah dimilikinya pada masa sebelumnya. Di dalam masa regressip terjadi suatu kemunduran balk fisik maupun psikhis. Pada masa ini ditemui masa krisis besar ketiga yang dialami manusia.

Dengan tidak mengabaikan masa-masa yang lain yang juga menentukan corak kehidupan, maka kita menitik beratkan

kemasa-masa krisis saja untuk menghantar kemasalah perbuatan kriminil. Masalahnya terletak bahwa masa krisis pertama merupakan masa penentuan, baik secara positif maupun negatip terhadap tingkah laku ataupun corak kehidupan kaiak. Riga masa krisis kedua merupakan masa peralihan antara masa kanak-kanak ke masa dewasa Pada saat ini ia harus dapat belajar untuk dapat menyesuaikan dirinya dalam kehidupan sosial sebaqai orang dewasa. Masa krisis ketiga merupakan krisis terakhir yang ditemukan pada usia setengah tua, dimana tubuh mulai menurun.

Sesuai dengan arti perkembangan, yakni suatu proses yang dimulai dan tingkat sederhana menuju kedifferensiasi dan variasi, kemudian terorganiser sebagai suatu gestalt. Seandainya

periode-periode krisis dalam perkembangan di dalam kehidupan

manusia itu tidak ada, tentu perkembangan itu akan berjalan tanpa mengalami kesulitan. Tetapi karena periode !crisis itu terdapat dalam perkembangan kehidupan manusia maka benturan-benturan terhadap kaedahkaedah dapat saja terjadi, bahkan dapat bersifat kriminil yang telah ditentukan oleh undang-undang hukum pidana. Ahli jiwa dalam mengatakan bahwa yang merupakan salah satu perbuatan manusia yang melanggar hukum ditentukan oleh instansi-instansi yang terdapat pada did manusia itu. Maksudnya perbuatan manusia pada dasarnya didasari oleh basic-needs yang menentukan aktivitas manusia itu. Hal tersebut diatas tidak lain disebabkan perbuatan manusia yang tidak-tidak mungkin dapat dipahami tanpa mempelajari kehidupan bahwa sadar dan tidal. sadar. Dengan kata lain isi yang ada dibawah sadar dan tidak sadar lebih berpengaruh dari pada isi kesadaran itu. Oleh karena itu pada ahli ilmu jiwa dalam ingin mencoba untuk menganalisa perbuatan manusia unnunnya dengan mencoba membahas unsur-unsur intern dan hidup pada jiwa manusia itu yang lazimnya disebut dengan the structure of personality.

Walaupun para ahli mempunyai perbedaan-perbedaan pembagian dalam mengemukakan tingkatan-tingkatan struktur-personaliti, tetapi jika diperhatikan titik tolaknya adalah sama. Struktur-personaliti terdiri dari tiga instansi, yakni das Es, das Ich dan das 
Uber Ich, istilah ini di Amerika Serikat disebut Id, Ego, Super Ego,

Menurut S. Freud (Bawengan, hal 84 dst), das Es (Id) adalah sumber sesuatu yang terlupa dan juga unsur-unsur kejiwaan yang dibawa bersama kelahiran. Unsur kejiwaan yang dibawa bersama kelahiran, misalnya Instink/Naluri yang mengatur pada organ fisik, antara lain naluri permusnahan/destructive-instinct, disamping itu terdapat juga contructive instinct yang dinamakan Libido. Jadi das Es (Id) adalah alam tak sadar yang merupakan Libido tak teroganiser yang berisikan dorongan-dorongan dan keinginan atau nafsu-nafsu tertekan yang ditolak oleh alam sadar.

Dorongan-dorongan, keinginankeinginan atau nafsu-nafsu menginginkan suatu pemuasan, dalam setiap saat berusaha untuk mencari jalan keluar. Tetapi agar pengalamannya jangan bertentangan dengan kaedah-kaedah dari kehidupan manusia yang berlaku muncullah das Ich (Ego) Das Ich (Ego) ini merupakan pusat seluruh perawakan jiwa dan khususnya inti dari pada slam sadar. Walaupun das Ich das Ich

merupakan jembatan yang menghubungkan kebutuhan dengan perbuatan, tetapi juga 'menyadari keadaan-keadaan yang terdapat diluar dan didalam did. Karena itu das Ich (Ego)

berusaha untuk menyesuaikan keinginan/nafsu dengan kaedah-kaedah amt., realitas yang ada. Dengan demikian akan terhindar sebanyak mungkin konflik yang bertentangan dengan kaedahkaedah. Kemungkinan das Ich (Ego) mengindenfiser did dengan realitas dan bersamaan dengan itu terbentuklah Uber Ich (Super Ego) Uber Ich merupakan instansi puncak jika dibandingkan dengan instansi lain (das Es dan das Ich).

Segala kaedah-kaedah dan tata kehidupan yang pernah mempengaruhi das Ich membekas dan berada pada das
Uber Ich. Instansi inilah yang mengkontrol segala, tindakan das Ich dan merupakan kehendak das Es. Kaedahkaedah dan tata kehidupan yang terdapat di dalam das Uber Ich diperolehnya dan

luar, yakni berupa pengalamanpengalaman yang pernah mempengaruhi das Ich dalam proses indentifikasi diri dengan lingkungannya. Jadi das Uber Ich merupakan alam kaedah/alam nilai yang mengawasi das Ich tentang apa yang dilakukan, sedang dilakukan, telah dilakukan. Penilaian-penilaian tersebut berupa teguran jangan melakukan dan

dapat juga untuk mengizinkan melakukan.

Sehubungan dengan alam nilai ini, kita sangat tertarik pendapat dari Alfred Adler mund dari S. Freud yang berpendapat bahwa agar jangan terjadi ketegangan,

maka harus ada keseimbangan (equilibrium) antara nilai kepentingan individu dengan nilai kepentingan masyarakat. Dengan kata lain ia menganjurkan adanya keseimbangan antara dorongan perasaan ingin lebih dengan perasaan kemasyarakatan.

\section{Kebebasan Hakim}

Dalam Penerapan Hukuman.

Sampailah kita pada tugas-tugas hakim atau kewajiban-kewajiban serta C)kebebasan hakim dalam menetapkan berat hukuman.

Robert Fisher, dalam tulisannya melihat adanya suatu hubungan antara perundang-undangan dengan hakim dan mencantumkan "Gewehnheitsrecht" sebagai sumber dalam yurisprudensi untuk mengikuti kehidupan masyarakat yang terus bergerak (Seno Adji, hal. 5)

Sehubungan dengan itu interpretasi amat diperlukan agar dapat mengikuti laju serta dinamika masyarakat seandainya undang-undang sulit mendapatkan perobahan. Karena itu kebebasan hakim untuk menentukan berat hukuman dapat bergerak dalam batas- 
batas maximal hukuman dan jenis hukuman. Meskipun demikian kebebasan tersebut bukanlah kebebasan, mutlak tanpa batas, kesewenang-wenangan subyektif dari hakim tidak dikehendaki, tetapi harus memperhitungkan sifat dan seriusnya peristiwa pidana yang dilakukan dan keadaan-keadaan yang meliputi perbuatan-perbuatan yang dihadapkan kepadanya.

Pertimbangan keputusan, seperti kepribadian pelaku perbuatan, usia, tingkat pendidikan pria/wanita lingkungan maupun kepribadian bangsa, perlu mendapat perhatian. Dengan kata lain pertimbangan kepentingan harus disesuaikan dengan kaedah-kaedah, alasan-s, dan keyakinan hukum yang berlaku didalam masyarakat dimana ia hidup. Karena bahan-bahan yang mengandung sosiologis dan psikologis tidak dapat diabaikan begitu raja. Disamping itu mengingat juga pandangan tentang adanya hak-hak azasi manusia yang dikaitkan dengan ukuran-ukuran bila seorang dipandang mampu bertanggung jawab sehingga keadilan dalam penerapan keputusan dapat tercipta

Permasalahan lain yang timbul bagi hakim, yakni teori hukum pidana yang mana haws dipergunakannya dalam rangka mengambil keputusan terhadap suatu perista pidana yang dihadapkan kepadanya Keputusan Hakim pada dasarnya diambil dalam tuduhan yang ditujukan terhadap terdakwa dan hasil pemeriksaan yang dilakukan dalam

persidangan peradilan. Seandainya tuduhan tersebut terbukti serta terdakwa dapat dihukum, maka hakim menetapkan berat hukuman berdasarkan teori Hukum Pidana yang dipergunakannya.

Dalam hal penggunaan teori Hukum Pidana, Hakim diberi kebebasan, karena perundang-undangan di dalam $\mathrm{KUH}$

Pidana, yurisprudensi, ilmu hukum/doktrin tidak menetapkannya
Meskipun demikian dalam prakteknya Hakim lazim mempergunakan teori gabungan di dalam menetapkan berat hukuman. Maksudnya walaupun Hakim diberi kebebasan untuk menetapkan berat hukuman antara batas maximal, tetapi bukanlah berarti harus ada penilaian yang bersifat subyektif dari Hakim, dan untuk itu Hakim dapat mempergunakan teori

gabungan, dimana setidak-tidaknya paham perlindungan atas pengamanan

kepentingan-kepentingan masyarakat tidak tinggalkan, disamping penghukuman terhadap sipembuat diperlakukan.

Disamping itu menjadi permasalahan juga tentang penyamaan berat hukuman dari peristiwa pidana yang sama. Umumnya ada tanggapan bahwa sesuatu itu baru dapat dianggap adil, jika setiap peristiwa-peristiwa pidana yang sama harus diperlakukan sama, dan setiap perisiwa-peristiwa pidana yang, tidak sama harus diperlakukan tidak sama. Mengenai hal ini secara praktis tidak semudah untuk diperlakukan seperti anggapan tersebut. Walaupun hal ini selalu dihadapkan kepada hakim, tetapi harus dimaklumi bahwa berat hukuman disatu pihak harus berlandaskan kepada keadaan-keadaan dari perbuatan (daad) dan pelakunya (dader), dan lain pihak dapat disamakan dengan berat hukuman di dalam peristiwa yang sama

...Akibat dari pada landasan, antara perbuatan (daad) dan pelakunya (dader) disatu pihak, dengan disamakan hukuman dalam peristiwa pidana yang sama, maka Hakim harus dapat bergerak. Hal ini eisebabican secara praktis peristiwa pidana yang dihadapkan kepadanya, dan diantara Hakim sendiri terdapat perbedaan pandangan tentang penilaian terhadap data-data dalam peristiwa pidana yang sama ataupun yang dapat disamakan. Yang perlu menjadi pemikiran adalah seberapa jauh Hakim 
dapat mengusahakan agar berat hukuman dari peristiwa pidana yang sama, sejenis atau dapat dipersamakan, mempunyai landasan pertimbangan, sehingga berat hukuman yang tak wajar dan tidak dibenarkau menjadi terhindar.

\section{KESIMPULAN}

1. Pengertian kejahatan sangat tergantung kepada penilaian dan jenis reaksi yang diberikan oleh masyarakat dimana terjadinya perbuatan itu.

2. Terdapatnya pergeseran-pergeseran terhadap nilai perbuatan yang telah ada, sehubungan dengan perbuatan sebagai gejala sosial.

3. Kejahatan dalam pengertian yuridis adalah perbuatan yang oleh Hukum Pidana secara definitif dinyatakan sebagai gejala perbuatan jahat.

4. Secara psikologis adanya pengaruh kejiwaan yang dapat menimbulkan keabnormalan individu dalam perbuatan yang dapat jahat, sesuai dengan penyimpangan terhadap kaedah-kaedah yang berlaku dalam suatu masyarakat.

5. Pertimbangan Psikologis perlu mendapatkan perhatian dalam proses pendidikan, penuntutan dan terutama proses peradilan.

6. KUH Pidana secara tegas mengatur tentangpengecualianhukuman,

peringan hukuman, pemberatan hukuman dan batas maximal berat hukuman dan mengadakan tambahan dengan tata tertib yang tidak terdapat dalam KUH Pidana disamping hukuman tambahan.

7. Interprestasi di perlukan agar dapat mengikuti laju serta dinamika masyarakat seandainya undangundang sulit mendapatkan perobahan.

8. Kebebasan Hakim untuk menentukan berat hukuman dapat bergerak dalam Batas batas maximal hunman dengan jenis hukuman serta kejiwaan sesuai dengan dasar-dasar pertimbangannya.
9. Dalam peristiwa-peristiwa pidana yang sama atau yang dapat disamakan bukanlah berarti berat hukumannya harus sama.

\section{DAFTAR PUSTAKA}

Abraharusen, David MD "Thee Psychology of Crime" University Press.New York \& London 1960

Bawengan, Gerson, Drs.SH; "Pengantar Psychology Kriminil" Pradnya Parimita, Jakarta Bonger WA "Pengantar Tentang Kriminologi" (Terjemahan) PT. Pembangunan, Jakarta 1973 Chainur Arrasjid, SH "Pengantar Ilmu Hukum Indonesia, Yani Corporation, Medan 1988 Chainur Arrasjid, SH "Pengantar Psikologi Kriminil" Yani Corporation, Medan, 1988

Calven S Mall, "Suatu Pengantar Kedalam Ilmu Jiwa" (Sigmund Freud), Terjemahan PT Pembangunan, Jakarta 1969

James Mashall, "Law And Psychology In Confltet" Anchor Books Doubleday \& Company Inc Garden City New York, 1969

Kartini Kartono, Dra, "Psykologi Abnormal" Alumni Bandung, 1972.

Oemar Seno Adji, Prof.S11; "Hukum Hakim Pidana" Erlangga, Jakarta 1984 Ruslan Saleh, Prof.SH, "Perbuatan Pidana dan Pertanggung Jawaban Pidana", Aksara Ban.' Jakarta, 1983.

Sahetapy, J.E. Prof.SH; "Hukum Dalam Konteks Sosial Politik dan Budaya" Kongres Kebudayaan 1991, Jakarta.

Sutherland - Cressey; "Principles of Criminology", J.B. Lippincolt Company New York 1960.

Soesilo, R, "Kitab Undang-undang Hukum Pidana" (KUHP) Politera, Bogor, 1988 Utrecht, F.Mr.Drs., "Hukum Pidana I" Pustaka Tinta Mas, Surabaya, 1986 